Canadian Journal of Higher Education

Revue canadienne d'enseignement supérieur

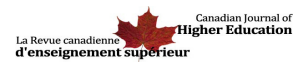

\title{
Bringing College Classrooms to the Community: Promoting Post-Secondary Access for Low-Income Adults Through Neighbourhood-Based College Courses
}

\author{
Alan Bourke, Jim Vanderveken, Emily Ecker, Jeremy Atkinson and Natalie \\ Shearer
}

Volume 49, Number 1, 2019

URI: https://id.erudit.org/iderudit/1060829ar

DOI: https://doi.org/10.7202/1060829ar

See table of contents

Publisher(s)

Canadian Society for the Study of Higher Education

ISSN

2293-6602 (digital)

Explore this journal

Cite this article

Bourke, A., Vanderveken, J., Ecker, E., Atkinson, J. \& Shearer, N. (2019). Bringing College Classrooms to the Community: Promoting Post-Secondary Access for Low-Income Adults Through Neighbourhood-Based College Courses. Canadian Journal of Higher Education / Revue canadienne d'enseignement supérieur, 49(1), 159-175. https://doi.org/10.7202/1060829ar

\section{Article abstract}

In this paper we utilize interview data to explore the workings of a collegecommunity partnership program that delivers tuition-free, for-credit courses to low-income adult students in neighbourhood-based settings. Addressing the interplay of individual and structural barriers on the educational readiness of students, our findings explore how the program builds participants' confidence and self-belief, and how the neighbourhood-based delivery model encourages their engagement with post-secondary education (PSE). We find that the value of embedding PSE capacity and resources in low-income communities lies not only in its potential to engage adult learners, but also in how it nurtures a greater sense of community integration and social inclusion. We conclude by suggesting that our study provides a useful foundation for institutions elsewhere aiming to recalibrate and extend their community outreach strategies when seeking to promote post-secondary access and engagement for low-income populations.
Copyright (c) Alan Bourke, Jim Vanderveken, Emily Ecker, Jeremy Atkinson, Natalie Shearer, 2019
This document is protected by copyright law. Use of the services of Érudit (including reproduction) is subject to its terms and conditions, which can be viewed online.

https://apropos.erudit.org/en/users/policy-on-use/ 


\title{
Bringing College Classrooms to the Community: Promoting Post-Secondary Access for Low-Income Adults Through Neighbourhood-Based College Courses
}

Alan Bourke, James Vanderveken, Emily Ecker, Natalie Shearer, \& Jeremy Atkinson Mohawk College

\begin{abstract}
In this paper we utilize interview data to explore the workings of a collegecommunity partnership program that delivers tuition-free, for-credit courses to low-income adult students in neighbourhood-based settings. Addressing the interplay of individual and structural barriers on the educational readiness of students, our findings explore how the program builds participants' confidence and self-belief, and how the neighbourhood-based delivery model encourages their engagement with post-secondary education (PSE). We find that the value of embedding PSE capacity and resources in low-income communities lies not only in its potential to engage adult learners, but also in how it nurtures a greater sense of community integration and social inclusion. We conclude by suggesting that our study provides a useful foundation for institutions elsewhere aiming to recalibrate and extend their community outreach strategies when seeking to promote post-secondary access and engagement for low-income populations.
\end{abstract}

\section{Résumé}

Dans le présent rapport, nous utilisons des données d'entrevues pour étudier le fonctionnement d'un partenariat collège-communauté qui offre gratuitement des cours à unités dans des établissements d'enseignement du voisinage à des étudiants adultes ayant un faible revenu. S'intéressant aux interactions entre 
les facteurs personnels et structurels qui ont une incidence sur le degré de préparation scolaire des étudiants, nos résultats montrent que le programme permet de développer l'assurance et la confiance en soi chez les participants et que le modèle communautaire de prestation des cours encourage les étudiants à poursuivre des études postsecondaires (EPS). Il ressort que la valeur d'intégrer des capacités et des ressources d'enseignement postsecondaire dans les quartiers à faible revenu réside dans la capacité du programme non seulement d'engager les apprenants adultes, mais aussi d'accroître leur inclusion sociale et leur intégration communautaire. En conclusion, nous suggérons que notre étude pose une assise probante pour les établissements d'enseignement d'ailleurs qui souhaitent revoir leurs stratégies d'approche communautaire et en étendre la portée afin de promouvoir l'accessibilité et l'attrait des études postsecondaires auprès des adultes à faible revenu.

\section{Introduction}

In Ontario, and across Canada, there is a pressing need to increase the post-secondary education (PSE) participation rate of under-represented groups, including adults from low-income communities, in light of shifting labour market demands and the growing need for educational qualifications (Anisef, Brown, \& Robson, 2013; Stonefish, Craig, \& O'Neill, 2015). Despite significant growth in the diversity of student populations attending Canadian post-secondary institutions (Michalski, Cunningham, \& Henry, 2017, p. 76), adults from low-income communities remain under-represented (Frempong, Ma, \& Mensah, 2012; Lange, Chovanec, Cardinal, Kajner, \& Smith Acuña, 2015; Pollock, 2012). Although a growing body of scholarship has emerged to document how low-income individuals face a wide range of financial and non-financial barriers affecting the accessibility of PSE (see, e.g., Lange et al., 2015; McMullen, 2011; Mueller, 2008; Robson, Anisef, \& Brown, 2014), there is a lack of research exploring the specific needs of low-income adults when it comes to encouraging their engagement with higher education (Flynn, Brown, Johnson, \& Rodger, 2011; Hyland-Russell \& Groen, 2011). In this paper, we draw on interview data to explore the workings of a college-community partnership program in an urban setting in Ontario that delivers tuition-free, for-credit courses to low-income residents in neighbourhood-based settings. We analyze students' perspectives on their educational readiness in light of the barriers to education that they face, and how the community-based delivery model encourages their engagement with PSE.

\section{Literature Review}

The barriers and challenges that adult learners face in accessing PSE are complex and varied. They are typically categorized in a threefold manner: situational barriers refer to an individual's life circumstances, such as financial constraints or family/ childcare commitments; institutional barriers refer to programmatic factors regarding the cost and accessibility of programs of study and knowledge of the application process; and dispositional barriers refer to the psychological facets of learning, such as feeling too old to return to school or lacking confidence in one's academic abilities (Cross, 1981; Donaldson \& Graham, 1999; Philibert, Allen, \& Ellevn, 2008; Flynn et al., 2011; Pinsent- 
Johnson, Howell, \& King, 2013). Because of the heterogeneity of adult learners, these barriers can coalesce in a wide variety of ways to form obstacles to learning. The challenges facing low-income adults seeking to return to education are considerably exacerbated by conditions of socio-economic precarity, including high rates of unemployment, low levels of educational attainment, feelings of social exclusion experienced during childhood, immigrant status, and factors related to ethnic or racial identity (Mueller, 2008; Abada, Hou, \& Rams, 2009; Prins \& Schafft, 2009; McMullen, 2011).

In aiming to build the academic skills of students, Canadian colleges and universities have sought to promote post-secondary accessibility for under-represented groups, including low-income adult learners, through continuing education and related initiatives. These initiatives can take a variety of forms, and include credit-based transition courses, financial support, counselling/advising regarding potential programs of study, academic upgrading services, and the provision of childcare (Bowering, Mills, \& Merritt, 2017; Childs, Hanson, Carnegie-Douglas, \& Archbold, 2017; Michalski et al., 2017). Such initiatives aim to mitigate the effects of situational barriers that students face, challenge institutional barriers, and effect an attitudinal shift in participants' academic confidence. Despite these efforts, low-income adults remain both under-represented and underserved in PSE (Frempong et al., 2012; Lange et al., 2015; Pollock, 2012). Anisef, Brown, and Robson (2013, p. 44) have highlighted the lack of efficacy of continuing education courses offered through school boards in facilitating the transition of adults from low-income communities to further courses of post-secondary study.

One explanation for this is the implicit conflation of access and engagement that often characterizes initiatives seeking to promote post-secondary participation. For example, Pollock (2012) contends that post-secondary institutions are more than sets of institutional policies and procedures; they also involve social and cultural processes that individuals from low-income communities find difficult to engage with. More broadly, Robson, Anisef, and Brown (2014) position the "plethora of assumed knowledge" (p. 16) that is required to successfully transition to the post-secondary level (knowledge of entry requirements, funding opportunities, application deadlines, and so on) as a form of cultural capital; that is, a form of tacitly understood knowledge that many non-traditional students often lack (Bourdieu, 1986; see also Childs, Finnie, \& Mueller, 2018). Although such perspectives are useful in exposing how class-based knowledge and competencies work to maintain post-secondary institutions as sites of social exclusion for low-income individuals, they risk compounding the workings of what Gorski (2012) calls the "deficit ideology" that often frames initiatives designed to improve the post-secondary participation rate of under-represented groups. In effect, such framing perpetuates a "culture of poverty"-style contextualization, whereby low-income individuals are seen to "share a consistent, predictable set of values and behaviours" (p. 302; see also Milner, 2008). Although previous research indicates that individuals from low-income groups have lower levels of post-secondary aspirations than individuals from higher socio-economic backgrounds (Marjoribanks, 2003), such perspectives risk reducing individuals to a series of deficiencies and inadequacies, with a concomitant discounting of the extent to which structural factors (such as a lack of accessible education, a dearth of well-paying jobs, a lack of affordable childcare, and factors associated with the experience of socio-economic exclusion) envelop and circumscribe their engagement with PSE (Prins \& Schafft, 2009). 
The difficulty in overcoming structural barriers (which compound the interplay of situational, institutional, and dispositional barriers) can result in low-income individuals engaging in what McInerney (2009) terms "acts of resistance" (p. 24), such as appearing not to value education or seeming withdrawn and disengaged. Such resistance can serve to further perpetuate the marginal status of individuals, as it sidelines the resources and resilience that they and their respective communities possess, in addition to minimizing the potential of their individual and collective agency (Hyland-Russell \& Groen, 2011). Contesting the notion of there being a culture of poverty in low-income communities, $\mathrm{Ru}-$ benson and Desjardins (2009) use the term "bounded agency" to highlight the necessity of understanding withdrawal or disengagement in light of the structural conditions that contextualize students' life circumstances.

A central contention of this paper is that building the individual and collective agency of low-income students involves developing strategies of post-secondary accessibility that nurture the growth of community-based "social relations" through concerted resident engagement at the grassroots level (Stephan, 2013, p. 19). Such thinking proposes embedding PSE capacity and resources in neighbourhood locations in a manner that builds on and extends more conventional forms of campus-community engagement, such as campusbased transition courses or continuing education courses run through local high schools. To date, however, Canadian post-secondary institutions have done little to explore the potential of using non-traditional settings (e.g., neighbourhood-based locations) to encourage the participation of under-represented groups in PSE (Stonefish et al., 2015). Writing on the benefits of a neighbourhood-based education hub in a low-income community in Winnipeg, Manitoba, MacKinnon and Silver (2015) cite the potential benefits of such approaches in terms of both the short-term "ripple effect" (e.g., when word of mouth spreads awareness of the benefits of an initiative) and the long-term "trickle-down effect" (e.g., a child is more likely to acquire a PSE if their parent has done so). In addition to boosting engagement with education, neighbourhood-based delivery models also help foster a greater sense of social inclusion and trust between low-income individuals and post-secondary institutions. As Pollock (2012) states, "Without trust, no initiative, intervention, or effort at partnering to provide access and/or student engagement, will come to fruition" (p. 10). A neighbourhood-based approach also positions post-secondary institutions, rather than communities or the individuals who reside in them, as deficient or lacking in their ability to encourage greater participation of individuals from low-income communities.

\section{Study Overview and Research Methods}

Our study is based on a college-community partnership program that delivers tuitionfree and for-credit college courses through two neighbourhood-based college classrooms in the community, called learning hubs. Participants may take up to two courses, which can be later applied to select programs of study in one of the college's post-secondary programs. Applicants must be 19 years or older and not currently enrolled in a post-secondary program of study. Priority is given to individuals with little or no PSE experience (i.e., those who may have dropped out of high school or who have no academic qualifications beyond a high school education) and who are not currently in the labour market. By bringing the classroom to the community, learning hubs aim to mitigate some of the institutional barriers that students may have faced in the past regarding the cost and ac- 
cessibility of a college education and the required knowledge of the application process. In addition, students are provided with support aimed at alleviating some of their situational barriers (courses are tuition-free and childcare is provided), with the ultimate aim of boosting students' confidence and raising their post-secondary aspirations. Launched in 2015, the first learning hub is located in a former school that has been repurposed as a community hub by a local residents' group. The second hub, operational since 2016, is situated in the city's central library.

The development of the learning hub model was the result of a two-year outreach and engagement process by the college. This included regular attendance at the monthly meetings of residents' groups, attendance at community events, consultations with neighbourhood social service providers, and "open table" events at neighbourhood locations such as cafes and libraries. Methodologically, we understand such community engagement to be what Bennet and Bennet (2007) term "collaborative entanglement," a dialogic process that remains responsive to the "intentional collision and interplay" (p. 18) of the knowledge and perspectives of all those involved. Through such engagement, we learned that barriers to education for residents include poverty, addiction, family or childcare issues, teen pregnancy, language challenges, and feelings of social exclusion. Both neighbourhoods have higher rates of social assistance dependency and lower rates of parental educational attainment than the municipal average, and high school dropout rates that are close to double the municipal average. A lack of educational readiness was identified by residents as the most significant barrier to their post-secondary participation. This includes a lack of confidence and/or interest in PSE, a lack of awareness of potential programs of study, and a lack of knowledge regarding the application process. Residents also reported a reluctance to travel to the college campus, and suggested the college engage them locally at convenient and familiar locations. Furthermore, they suggested the college offer short introductory for-credit courses that could serve as confidence-builders for those with an interest in pursuing a post-secondary course of study.

Two additional reasons informed the decision to deliver courses in neighbourhood locations rather than high schools (as is common in the delivery of continuing education courses). First, we were mindful that potential students may have had a past negative experience of high school and/or been high school dropouts. Seeking to build a relationship of trust, we thus sought to avoid the program "feeling" like high school. Second, we were cognizant that a significant number of potential students would likely be social service recipients. As such, we sought to place classrooms in locations that catered to such populations (as in the case of the community centre location), or venues that residents suggested served as neighbourhood gathering places (as in the case of the central library location). Course scheduling and focus (as selected from the college's day program) was decided in consultation with residents. The courses ran for 10 weeks, with an average of 14 students per course. In the following list of courses, the first number refers to the number of enrolled students, and the second to the number of students who completed the course (also given as a percentage). The first learning hub saw the delivery of three courses: Introduction to Health and Wellness (9/5 [55.5\%]), Health Safety and Nutrition (17/14 [82.3\%]), and Family Dynamics (12/4 [33.3\%]). The courses Digital Photojournalism (20/14 [70\%]) and Introduction to Postsecondary Experiences (14/5 [35.7\%]) were delivered at the second location. Out of a total of 72 enrolled students across the five courses, the average course completion rate was $55.4 \%$. 


\section{Participant Overview and Interview Procedure.}

Over the course of fall 2016 and winter 2017, we conducted 20 semi-structured interviews with students who had completed at least one for-credit course at either of the hub locations. Following course completion, all enrolled students were contacted by phone and/or email with a request for an interview. Interviewed students represent $47.6 \%$ of students who completed a course and $27.7 \%$ of enrolled students overall. Interviews were conducted by two members of the research team, took place at either location, and ranged in length from 35 to 75 minutes. The sample was composed of 15 female students and five male students, who ranged in age from 19 to 64 (the average age was in the early 30s). Of the 20 students interviewed, seven had completed two courses (the maximum allowed). More than half of the individuals in the sample were either first- or second-generation students, with approximately $68 \%$ having completed high school. Two students had experience of attending university in the past, but had dropped out before completion. Information on the specific demographic and personal characteristics (e.g., visible minority status, ethnicity, employment history) of enrolled students was not collected, in compliance with our institutional commitment toward ensuring participants' confidentiality and in order to make the enrollment process as barrier-free as possible.

Interviewed students were asked a range of questions pertaining to their previous educational experiences, the barriers to education they face, and their experience of taking a course. Our focus on the views and perceptions of students is designed to address what Jones and Lee (2017, p. 176) see as the absence of resident voice in research on community-campus engagement initiatives, as well as the paucity of studies that specifically address the experiences of marginalized adult learners (Flynn et al., 2011). Interview transcripts were analyzed by the research team using a process of thematic analysis, a method used to identify, analyze, and discuss patterns and themes emerging from the data. In essence, thematic analysis is an interpretative process of meaning-making in which key themes and subthemes are identified and categorized (Braun \& Clarke, 2006). In selecting themes, we sought to differentiate between the range of (situational and dispositional) barriers students face in light of their individual challenges and the extent to which the interplay between these impact their engagement with course material and overall course experience. Our identification and refinement of themes was also informed by the scholarship on post-secondary access and engagement, as addressed in our literature review. A challenge we faced in analyzing interview data was that the connections students made to structural or systemic factors were often thinly sketched. During interviews, for example, students typically moved from alluding to structural factors (e.g., a lack of meaningful employment opportunities or a lack of childcare support) to describing the effects of these factors at an individual level in situational and/or dispositional terms. Although mindful of how low-income adults can identify "individual solutions to collective structural problems" (Silva, 2013, p. 146), our analysis focuses primarily on themes pertaining to students' shifting perceptions of their educational readiness and course experience in light of the neighbourhood-based delivery model.

Our research raised a number of methodological considerations. Although we contacted all enrolled students with an interview request, including those who failed to complete a course, the sample is composed only of successful completers. Information gleaned from 
follow-up phone calls with students who failed to complete a course indicates an employment opportunity or childcare or family responsibility as the reason for not continuing in a course. Although the lack of systematic data on course non-completers is a methodological limitation, the students we did interview had a wide range of both positive and negative experiences with PSE, and were thus knowledgeable regarding the barriers and challenges faced by individuals in their community. Finally, we were mindful of how our identity as college researchers could potentially shape the interview process, particularly in terms of our social location as representatives of an educational institution that participants may feel alienated from. Despite this, we found participants eager to engage with our questions, with the interviews yielding accounts rich in experiential detail.

\section{Findings}

In presenting our findings, we begin by exploring students' perspectives on their educational readiness in light of the individual and structural barriers they face in accessing PSE. We then address how course design and delivery help build student confidence and how bringing college classrooms to the community encourages post-secondary engagement.

\section{Students' Perspectives on Their Educational Readiness}

A common theme in the interviews was students' lack of educational readiness because of the situational barriers and/or individual challenges they faced. Such commonly cited situational barriers as financial hardship, unemployment (or underemployment), and childcare or family commitments were often compounded by a wide range of individual challenges related to age, immigrant status, health (including mental health), disability, and ESL status. From the outset, however, it should be noted that participants varied widely in terms of the extent to which the barriers and/or challenges they faced affected their level of educational readiness. As such, a lack of educational readiness does not necessarily mean that students lack confidence in their academic abilities. While some students did describe themselves as lacking confidence in their academic abilities, others mentioned feeling despondent due to a lack of direction or having difficulty identifying a potential educational pathway. Nonetheless, the cumulative effect of the barriers or challenges that students faced was typically described in dispositional (or psychological) terms. As one student noted:

I think I had a few different things running around in the back of my mind. One was just to get myself back in the frame of mind of going to school.... I've been out of the workforce long enough and, you know, I really am feeling like I want to move forward in some way...and trying to find a direction is difficult. (Interview 1)

Throughout the interviews, the prospect of returning to school was a recurring "back of my mind" sentiment, and enrolling in a course allowed students to ease themselves into a post-secondary environment. A common theme across interviews was a past negative educational experience of high school, or a previous "false start" in a post-secondary environment. For example, one student spoke of enrolling in a course in order to "see what it would be like. I've been through many different schooling things and I've always cancelled or dropped out, whatever. So, it was to see, okay, am I ready now?" (Interview 17). Such 
sentiments were echoed throughout the interview narratives in terms of the compounding interplay of situational barriers (e.g., time spent out of work and/or school) and dispositional barriers (e.g., self-perception as lacking direction). Another student commented:

I just wanted to make sure I was still up to par with things. But it was initially just being scared and not knowing if I could do it. When it comes to things like this, most people have had enough difficulties in life, like your self-esteem and everything, it gets you down, and then you start questioning every choice you make, every move you make. (Interview 3 )

Such commonly expressed sentiments of anxiety and self-doubt evoke the notion of adult students as "wounded learners" (Lange et al., 2015, p. 208), as past experience and what the student quoted above refers to as "difficulties in life" have led students to doubt their ability to be academically successful. To a large extent, students' comments also echoed previous research, particularly in terms of how increased time spent away from formal education and/or a previous negative experience of education results in a lack of confidence and poor self-conceptualization as students (Anisef et al., 2013). Although students reported being initially apprehensive when signing up for a course, a unifying theme across interviews was their appetite for further education, despite being uncertain of where it could take them.

\section{Students' Understanding of Structural Barriers}

All students struggled with either periodic or chronic financial insecurity, and several spoke extensively of the lack of meaningful employment or educational opportunities available to them. One student remarked that "the economy in Ontario has changed much over the years and that's, I guess, the beginning of the difficulties I have faced" (Interview 1). Another student suggested the following connection between the effects of an economic downturn and the post-secondary aspirations of low-income individuals: "I think that maybe because the economy is not so good, people get lots of stress...and so they don't have much passion" (Interview 5). For many students, enrolling in a course was a tentative step in working to overcome the cumulative impact of the barriers and challenges they faced. Commenting on his struggle to overcome a learning disability and an extended period of unemployment, one student commented that "everything I feel right now in my life is about what I'm doing to help myself get stronger, understand that word stronger as best as I can, reflect on my life with my strength" (Interview 14). Although the central rationale of the program is to build students' academic skills and to encourage them to consider a further course of post-secondary study, such comments illustrate the benefits of the program in nurturing a sense of personal growth.

One area in which structural barriers became apparent had to do with childcare commitments. Previous research has illustrated how a lack of available childcare can work to deny women the opportunity to pursue an education and undermine their confidence, with such social constraints operating as a form of (gendered) social exclusion (Prins, Willson Toso, \& Schafft, 2009, p. 338). Two students recalled how being teenage mothers had limited their educational aspirations:

Having a young child and not knowing what to do or where to go...I didn't know what was out there. So, finally now that he's in school, I can venture out and do 
my own thing.... I struggled all through [high] school. Schooling is or wasn't really fun for me, but now I'm enjoying it more...now that I see that there are programs out there and that they are things that I can do and get back to where I want to be. (Interview 8).

I was a mom at a young age, at $16 \ldots .$. So, it [education] was just something I didn't have time for.... He's [her son] at the age now where he's a teenager. He doesn't want to go to school. I mean, he does, but he doesn't. He wants to go [because] of his friends. He doesn't want to go for the education. So, I wanted to show him that I can go far and that it's not too late. I want him to not make the same mistakes I did. (Interview 12)

Countering the notion of there being a culture of poverty by demonstrating an awareness of the intergenerational benefits of education, such comments illustrate the strength of resolve and resilience that resonate throughout many of the interview narratives. In essence, the interview data provide insights into how disengagement from the educational process is a multi-dimensional rather than singular event, one that often involves the complex interplay of a range of individual and structural constraints over the course of years.

\section{Students' Engagement with Course Content}

A common feature of the courses students enrolled in was assignments that presented opportunities for self-reflection on life experiences. Students in Family Dynamics, for example, completed a "family map" assignment in which they mapped the support they had in their lives. As one student commented, "I found out [that] I have only a few people whom I really care about. So, it showed me my real life, and to whom I can go to in a crisis" (Interview 15). Commenting on relating content from the Health, Safety, and Nutrition course to their everyday lives, the following student suggested:

I think having more information to, you know, help me with my kids, right. Because, you know, safety, nutrition, everything will help, so yeah, I like to be more educated about stuff you use every day. Even at home or at work it's very important to know this information. (Interview 9)

These comments support previous research illustrating how adult learners can engage new knowledge in practical and more immediately useful ways than traditional-age students (Donaldson \& Graham, 1999, p. 32). Opportunities for reflection also evoke what Zyngier (2011) calls the confidence-building effects of "pedagogical reciprocity" (p. 226). This approach includes establishing connection (linking course content to what students know), ownership (encouraging students to see themselves and their life-worlds in their work), responding (e.g., to lived experience), and empowerment (encouraging students to become active participants in their learning).

In the Digital Photojournalism course, students signed out cameras for a project that required them to document subjects in their community. In completing this assignment and others like it, students were able to draw upon their "funds of knowledge," a term used by Lalas and Valle (2007) to describe the "interconnections and networks" (p. 77) of students' identities, families, and communities. In the Introduction to Postsecondary Experi- 
ences course, students completed a "personal profile" assignment that required them to reflect on the educational barriers they faced in relation to their readiness for college, and the associated stresses that being a college student can entail. As one student remarked:

We had to do a profile on ourselves and I think that was the hardest thing for everybody...because you had to.... It put you in the position to really think about yourself, your needs, and your wants down the road. I think that's what woke most of us up. (Interview 3)

The same student spoke of the importance of building confidence in her academic abilities through engagement with course content and activities: "When that [academic] part clicked for me...that was pretty much it then. After that it was like, well, I can do this!" (Interview 3). Other students described arriving at such an "I can do this!" moment as key in helping them to successfully complete the course. One student spoke of how the "payoff" achieved through committing to a course led to a valuable sense of self-achievement: "You know what, you just have to be into it...you have to be committed...at the end when you finish you say to yourself...you've achieved something...you feel like you're proud of yourself" (Interview 11). This student's comment resonated throughout the interview narratives, with students describing an initial sense of caution giving way to a feeling of achievement and ownership over course content.

A challenge in course design lay in providing students with material that would present them with a challenging learning opportunity and provide them with forms of assessment that allowed them to demonstrate their learning, while at the same time not making the courses too intimidating and so damaging their emergent confidence. One student's comments point to success in this regard:

It really helped take away the unknown. It wasn't as scary, especially when you don't know where you want to go or where to start or anything. It gave you some options. It let you know what was out there. (Interview 12)

Although demonstrating flexibility with regard to course pacing and (especially) assignment deadlines was crucial to ensuring student success, some participants questioned this in terms of its comparability to a "regular" college course. Commenting on the degree of deadline flexibility she was granted in her course, one student suggested:

The assignments were good [but], I mean, we didn't really have deadlines. [The professor] told us to hand them in basically by the end of [the course] ...but I wish we would have got deadlines because that's real life, that's college, right? (Interview 19).

When asked about how they felt the program could be improved, however, students were typically less forthcoming. We remain mindful of how students' retrospective assessment of their experience has been influenced by the confidence-boosting effect of having successfully completed the program. 


\section{Students' Perspectives on the Classroom in the Community}

Throughout the interviews, students spoke favourably of how the neighbourhoodbased location helped them concentrate more fully on engaging with course content, in addition to alleviating concerns regarding the cost of transportation or childcare. Commenting on the downtown learning hub location, one student commented:

I have spoken to so many people, and they were highly impressed with what we learned and the time that they [faculty] gave us. This place is very easy to come to. It's not far away. You don't have to travel much. If you are downtown, this is the best place you can come. (Interview 15)

The convenience and familiarity of the classroom location was also strengthened by the location of the learning hubs inside pre-existing community focal points. For example, students taking a course in the central library could also access additional services provided by the library (e.g., access to computers, printing facilities, and meeting spaces). This highlights the importance of building on existing neighbourhood-based services and facilities, and the value of the community hub as a "gathering place" for resident activities (Haig, 2014, p. 1024). As one student noted:

When we were working on our class assignment we'd come in and we'd use the resources here in the library on the fourth floor, which are wonderful.... We really helped and encouraged each other in using the facilities on this floor. (Interview 1)

While students were initially apprehensive in advance of completing their first assignment, the fact that such sentiments were collectively shared helped to alleviate some of the anxieties they experienced. Such views illustrate the community-building aspects of the shared experience of taking a course in a familiar and non-threatening location, as students worked together to negotiate the college experience. Such comments also highlight how engaging with a taste of PSE can be both an individual and collective process. On this note, the student just quoted commented on the value of the program as follows:

I think the common link between myself and the others in my class is that many people are feeling that they need a kind of a jump-start, if you will. A lot of us probably felt like we needed that confidence boost, and whether it's going to school for the first or second time, quite a few of us were thinking seriously of taking school again. (Interview 1)

In essence, our findings suggest that the program offers significant promise for building the self-confidence of students and boosting their educational readiness. For the majority of students, taking a course was the catalyst they needed to encourage them to consider pursuing a future course of post-secondary study. One student noted, "I had a dream to do this and I wanted to take it. I'm finally taking the step that I want to do. There's a lot of good things out of this now" (Interview 6). Furthermore, for students interested in exploring their post-secondary options, acquiring what one student described as a "credit in the bag" (Interview 11) upon successful course completion was also a significant benefit of the program. 


\section{Conclusion}

Our findings have provided insight into the multi-dimensional nature of the challenges that low-income adults face when seeking to return to education. Exploring the interplay of individual and structural barriers, our analysis testifies to the confidence-building effects of the program and the ways in which students began to construct a sense of themselves as college students as they engaged with course content and the college experience. Having the opportunity to take a course in a convenient and familiar neighbourhoodbased setting allowed students to explore and/or revive their post-secondary aspirations without having to struggle with, or definitively overcome, the barriers and challenges they have faced in the past. There is currently a lack of evidence on how such neighbourhoodbased approaches can benefit underserved groups by promoting engagement with PSE, and our analysis has contributed to this discussion.

Although the generalizability of our findings is limited by the contextual specificity of the study, we suggest that its lessons have relevance for post-secondary institutions elsewhere. We contend that the value of embedding PSE capacity and resources in neighbourhood-based locations lies not only in its potential to engage difficult-to-reach populations but also in how it nurtures a greater sense of community integration and social inclusion (Michalski, et al., 2017; Riele, 2006). Zyngier (2011), writing in the Australian context, claims that access initiatives promoting the greater participation of under-represented groups in PSE often merely aim to "bring the disadvantaged to the same table at which the advantaged are already eating" (p. 214). Developing an access initiative in collaboration with residents, however, positions community participants as "partners in education equity" (Gorski, 2013, p. 50). As a programmatic response to what residents identified as a lack of accessible education and the difficulties of returning to PSE, the model marks a significant point of evolution beyond traditional modalities of community engagement, such as campus-based transition courses or continuing education courses offered through local high schools. Furthermore, by placing the learning hubs inside existing community hubs (in this case, a community centre and a library location), classrooms are strategically placed to connect residents with amenities and social support services aimed at lowincome individuals. In this, the initiative aligns with a provincial initiative in Ontario to use community hubs (conceived as neighbourhood gathering places) as a way to localize the delivery of social services to underserved populations (Pitre, 2014). In light of this, it is important to acknowledge the potential community-building effects of the program, such as encouraging individuals to connect with people and resources in the community, motivating them to take advantage of available post-secondary opportunities, and helping them to remain hopeful when working to overcome the barriers they face.

We are mindful of a number of remaining challenges regarding our research on the learning hub model. A first challenge lies in gathering data on students who failed to complete a course. Although our findings have provided insight into how the initiative works to mitigate some of the barriers to education that low-income students face, we recognize that those who responded to our interview request typically had a positive course experience. We are cognizant of the exclusion of a student demographic for whom successfully pursuing a post-secondary course of study is a far more remote and precarious prospect. To this end, any outreach strategy seeking to engage such demographics needs to be sen- 
sitized to the specificity of the targeted populations, while also acknowledging differences within and between communities. For example, further research could address the needs and experiences of specific groups, such as recent immigrants and Indigenous populations.

A second challenge lies in ensuring that students who do transition to a full-time program of study have the support they need. It is one thing to take a course in a comfortable and non-threatening community-based classroom, characterized by small class sizes and supportive faculty, but quite another to enroll in a full-time program of study with a full course load, a larger student cohort, less flexibility when it comes to assignment deadlines, and less direct contact with faculty. As such, it is imperative that follow-up support be available to students in the form of financial support, academic guidance, and career counselling.

A third challenge is that we remain aware of the systemic limitations of the neighbourhood-based courses as an intervention. The initiative may help raise students' post-secondary aspirations, yet it has limited capacity to address the full range of barriers and challenges they face. Although individuals act as purposeful agents in constructing their educational pathways, our findings suggest that the decisions students make cannot be considered in isolation from the economic and structural conditions impacting their communities. As noted by Lalas and Valle (2007), writing in the context of the United States, PSE access initiatives can remain dwarfed by the "power of urban poverty" (p. 76). Acknowledging this involves recognizing that educational institutions are by themselves unable to counter the systemic and structural challenges of socio-economic disparity and inequality that students face (Riele, 2006, p. 69). We remain cognizant of how programmatic responses working to promote post-secondary access and engagement cannot solve entrenched poverty in isolation from poverty reduction strategies enacted at the municipal and provincial levels. Nonetheless, our findings provide a useful foundation for institutions elsewhere aiming to recalibrate and extend their community outreach strategies when seeking to promote postsecondary access and engagement among low-income populations.

\section{Acknowledgments}

The authors would like to thank Martin Dooley, two anonymous reviewers, and the Community Access and Engagement team at Mohawk College for their input. A special thanks to the students who shared their experiences with us. This research was supported by funding through SSHRC's Community College Social Innovation Fund (CCSIF).

\section{References}

Abada, T., Hou, F., \& Rams, B. (2009). Ethnic differences in educational attainment among the children of Canadian immigrants. Canadian Journal of Sociology, 34(1), 1-28. https://journals.library.ualberta.ca/cjs/index.php/CJS/article/view/1651

Anisef, P., Brown, R., \& Robson, K. (2013). Non-traditional postsecondary education pathways of adult learners in the Toronto District School Board: Evaluating the influence of individual and neighbourhood characteristics. Toronto, ON: Higher Education Quality Council of Ontario.

Bennet, A., \& Bennet, D. (2007). Knowledge mobilization in the social sciences and humanities: Moving from research to action. Frost, WV: MQI Press. 
Bourdieu, P. (1986). The forms of capital. In J. G. Richardson (Ed.), Handbook of theory and research for the sociology of education (pp. 241-258). New York, NY: Greenwood Press.

Bowering, E., Mills, J., \& Merritt, A. (2017). Learning how to learn: a student success course for at risk students. Canadian Journal for the Scholarship of Teaching and Learning, 8(3), Article 12. https://doi.org/10.5206/cjsotl-rcacea.2017.3.12

Braun, V., \& Clarke, V. (2006). Using thematic analysis in psychology. Qualitative Research in Psychology, 3(2), 77-101. https://doi.org/10.1191/1478088706qpo63oa

Childs, R. A., Hanson, M., Carnegie-Douglas, S., \& Archbold, A. (2017). Investigating the effects of access initiatives for underrepresented groups. Perspectives: Policy and Practice in Higher Education, 21(2-3), 73-80. https://doi.org/10.1080/13603108.201 6.1231720

Childs, S., Finnie, R., \& Mueller, R. (2018). Assessing the importance of cultural capital on post secondary education attendance in Canada. Journal of Further and Higher Education, 42(1), 57-91. https://doi.org/10.1080/0309877X.2016.1206853

Cross, K. P. (1981). Adults as learners. San Francisco, CA: Jossey-Bass.

Donaldson, J., \& Graham, S. (1999). A model of college outcomes for adults. Adult Education Quarterly: A Journal of Research and Theory, 5O(1), 24-40. https://doi.org/ 10.1177\%2F074171369905000103

Flynn, S., Brown, J., Johnson, A., \& Rodger, S. (2011). Barriers to education for the marginalized adult leaner. Alberta Journal of Educational Research, 57(1), 43-58. https://journalhosting.ucalgary.ca/index.php/ajer/article/view/55454

Frempong, G., Ma, X., \& Mensah, J. (2012). Access to postsecondary education: Can schools compensate for socioeconomic disadvantage? Higher Education, 63(1), 19-32. https://doi.org/10.1007/s10734-011-9422-2

Gorski, P. (2012). Perceiving the problem of poverty and schooling: Deconstructing the class stereotypes that mis-shape education practice and policy. Equity and Excellence in Education, 45(2), 302-319. https://doi.org/10.1080/10665684.2012.666934

Gorski, P. (2013). Building a pedagogy of engagement for students in poverty. Phi Delta Kappan, 91(1), 48-52. https://doi.org/10.1177\%2Foo3172171309500109

Haig, T. (2014). Equipping schools to fight poverty: A community hub approach. Educational Philosophy and Theory, 46(9), 1018-1035. https://doi.org/10.1080/o013 1857.2014.931006

Hyland-Russell, T., \& Groen, J. (2011). Marginalized non-traditional adult learners: Beyond economics. Canadian Journal for the Study of Adult Education, 24(1), 61-79. https://cjsae.library.dal.ca/index.php/cjsae/article/view/125

Jones, D. O., \& Lee, J. (2017). A decade of community engagement literature: Exploring past trends and future implications. Journal of Higher Education Outreach and Engagement, 21(3), 165-18o. http://openjournals.libs.uga.edu/index.php/jheoe/ article/view/1884 
Lalas, J., \&Valle, E. (2007). Socialjusticelenses and authentic studentvoices: Enhancing leadership for educational justice. Educational Leadership and Administration: Teaching and Program Development, 19, 75-102.

Lange, E., Chovanec, D., Cardinal, T., Kajner, T., \& Smith Acuña, N. (2015). Wounded learners failed by schooling: Symbolic violence and re-engaging low-income adults. Canadian Journal for the Study of Adult Education, 27(3), 83-104. https://cjsae.library. dal.ca/index.php/cjsae/article/view/3901

MacKinnon, S., \& Silver, J. (2015). Tackling poverty through holistic, interconnected, neighbourhood based intergenerational learning: The case of Winnipeg's Selkirk Avenue. Universitas Forum: International Journal on Human Development and International Cooperation, 4(2). http://www.universitasforum.org/index.php/ojs/article/view/185

Marjoribanks, K. (2003). Family background, individual and environmental influences, aspirations, and young adults. Educational Studies, 29, 233-42. https://doi. org/10.1080/03055690303283

McInerney, P. (2009). Toward a critical pedagogy of engagement for alienated youth: Insights from Freire and school-based research. Critical Studies in Education, 5O(1), 2335. https://doi.org/10.1080/17508480802526637

McMullen, K. (2011). Postsecondary education participation among underrepresented and minority groups. Educational Matters: Insights on Education, Learning, and Training in Canada, 8(4). Ottawa, ON: Statistics Canada, Catalogue no. 81-004-X. Retrieved from https://www150.statcan.gc.ca/n1/pub/81-004-x/2011004/article/11595-eng.htm

Michalski, J., Cunningham, T., \& Henry, J. (2017). The diversity challenge for higher education in Canada: The prospects and challenges of increased access and student success. Humboldt Journal of Social Relations, 1(39), 66-89. https://digitalcommons. humboldt.edu/hjsr/vol1/iss39/11/

Milner, R. (2008). Disrupting deficit notions of difference: Counter-narratives of teachers and community in urban education. Teaching and Teacher Education, 24(6), 1573-1598. https://doi.org/10.1016/j.tate.2008.02.011

Mueller, R. E. (2008). Access and persistence of students from low-income backgrounds in Canadian postsecondary education: A review of the literature. Toronto, ON: Educational Policy Institute.

Philibert, N., Allen, J., \& Ellevn, R. (2008). Non-traditional students in community colleges and the model of college outcomes for adults. Community College Journal of Research and Practice, 32(8), 582-596. https://doi.org/10.1080/10668920600859913

Pinsent-Johnson, C., Howell, S., \& King, R. (2013). Returning to high school in Ontario: Adult students, postsecondary plans and program supports. Toronto, ON: Higher Education Quality Council of Ontario.

Pitre, K. (2014). Community hubs in Ontario: A strategic framework and action plan. Retrieved from http://www.ontario.ca/page/community-hubs-ontario-strategicframework-and-action-plan 
Pollock, K. (2012). Access, engagement, and community connections. Teaching and Learning, $7(2)$, 1-15. https://journals.library.brocku.ca/teachingandlearning/index. $\mathrm{php} / \mathrm{home} /$ article/view/414

Prins, E., \& Schafft, K. (2009). Individual and structural attributions for poverty and persistence in family literacy programs: The resurgence of the culture of poverty. Teachers College Record, 111(9), 2280-2310. http://www.tcrecord.org/Content. asp?ContentId $=15396$

Prins, E., Willson Toso, B., \& Schafft, K. A. (2009). "It feels like a little family to me": Social Interaction and support among women in adult education and family literacy. Adult Education Quarterly: A Journal of Research and Theory, 59(4), 335-352. https:// doi.org/10.1177\%2Fo741713609331705

Riele, K. (2006). Schooling practices for marginalized students-practice with hope. International Journal of Inclusive Education, 10(1), 59-74.

Robson, K., Anisef, P., \& Brown, R. S. (2014). Identifying the complexity of barriers faced by marginalized youth in transition to postsecondary education in Ontario: Ontario Human Capital Research and Innovation Fund Final Report. Toronto, ON: Ministry of Training, Colleges, and Universities. Retrieved from https://gatewaycities. mcmaster.ca/publications/publication-documents/robson-brown-ansifef-2015.pdf

Rubenson, K., \& Desjardins, R. (2009). The impact of welfare state regimes on barriers to participation in adult education: A bounded agency model. Adult Education Quarterly: A Journal of Research and Theory, 59(3), 187-207. https://doi. org/10.1177/0741713609331548

Silva, J. (2013). Coming up short: Working-class adulthood in an age of uncertainty. New York, NY: Oxford University Press.

Stephan, J. L. (2013). Social capital and the college enrolment process: How can a school program make a difference? Teachers College Record, 115(4), 1-39. http://www. tcrecord.org/Content.asp?ContentId=16915

Stonefish, T., Craig, J., \& O’Neill, A. (2015). The recruitment of under-represented groups to Ontario colleges: A survey of current practices. Toronto, ON: Higher Education Quality Council of Ontario.

Zyngier, D. (2011). (Re)conceptualizing risk: Left numb and unengaged and lost in a no-man's lands or what (seems to) work for at-risk students. International Journal of Inclusive Education, 15(2), 211-231. https://doi.org/10.1080/13603110902781427

\section{Contact Information}

Alan Bourke

Mohawk College, Hamilton

alan.bourke@mohawkcollege.ca

Dr. Alan Bourke is a professor in the Department of Liberal Studies at Mohawk College. He has research specializations in the critical analysis of campus-community engagement initiatives, higher education, PSE access and engagement, and qualitative research methods. 
James Vanderveken is Dean of the Centre for Community Partnerships and Experiential Learning at Mohawk College. He directs and oversees a wide range of post-secondary initiatives related to the College's community access and engagement strategy, and has extensive experience in partnership development, project management, and campus-community engagement. James leads the College's initiatives in developing and implementing community-based solutions to bringing post-secondary education to vulnerable communities.

Emily Ecker is Associate Dean of the Centre for Community Partnerships and Experiential Learning at Mohawk College. She plays a key role in guiding the College's access and engagement strategy in working to reduce barriers to post-secondary participation. Emily promotes an "out of the box" approach to collaborations with internal and external stakeholders to identify, develop, and evaluate community-based educational and employment opportunities.

Natalie Shearer has worked as a training specialist in Community Access and Engagement at Mohawk College and currently serves as the College's Manager of Industry and Community Engagement for Applied Research. She has extensive experience in community development, program planning, and supporting initiatives that respond to the strengths and needs of the community.

Jeremy Atkinson conducts research in post-secondary education and psychology, and has extensive experience and expertise in research project and survey design, statistical analysis, student enrolment and retention, and student satisfaction. 